\title{
Previous Labeling Company
}

National Cancer Institute

\section{Source}

National Cancer Institute. Previous Labeling Company. NCI Thesaurus. Code C125196.

The company that was formerly responsible for labeling a medical device. 